\title{
O papel do Centro IDEA-UMinho na transição para o ensino online durante a pandemia COVID-19: enfrentar desafios e criar oportunidades
}

\author{
https://doi.org/10.21814/uminho.ed.24.8
}

\section{Gabriel Gerber Hornink}

Gabriel Gerber Hornink (ORCID: 0000-0003-0388-4027) é biólogo, professor no Departamento de Bioquímica, Instituto de Ciências Biomédicas (ICB), da Universidade Federal de Alfenas (Unifal-MG) e atua nos grupos de pesquisa Inovações Tecnológicas no Ensino e Bioquímica InterAção, ambos na mesma universidade. A sua atuação está focada no desenvolvimento e avaliação de tecnologias digitais para o Ensino e na formação docente para o uso de tecnologias. Em 2020, desenvolve um estágio avançado de pós-doutoramento no Instituto de Educação da Universidade do Minho, no âmbito do Centro IDEA-UMINHO.

\section{Flávia Vieira}

Flávia Vieira (ORCID: 0000-0002-6932-4009) é Professora Catedrática no Instituto de Educação da Universidade do Minho e investigadora do Centro de Investigação em Educação (CIEd) da mesma Universidade. A sua atividade académica incide na formação reflexiva de professores, na transformação da pedagogia universitária e no desenvolvimento da autonomia em contexto educativo. Integra o Centro de Inovação e Desenvolvimento do Ensino e da Aprendizagem na Universidade do Minho (Centro IDEA-UMINHO) desde a sua fundação em 2017.

\section{Manuel João Costa}

Manuel João Costa (ORCID: 0000-0001-5255-4257) é Pró-Reitor dos Assuntos Estudantis e Inovação Pedagógica da Universidade do Minho. É bioquímico, professor da Escola de Medicina e investigador do Instituto de Investigação de Vida e Saúde (ICVS) da mesma Universidade. A sua atividade académica tem incidido sobre a inovação nas práticas pedagógicas no ensino superior e sobre a investigação da educação na área da saúde, em particular na educação médica, tendo participado na fundação do Centro de Inovação e Desenvolvimento do Ensino e da Aprendizagem na Universidade do Minho (Centro IDEA-UMINHO). 


\section{"O IDEA é feito de todos e para todos."}

(Coordenador do Centro IDEA-UMinho, Manuel João Costa, 2020)

\section{INTRODUÇÃO}

A Reforma de Bolonha em Portugal originou um movimento de valorização da docência nas instituições de Ensino Superior (IES), visível em reformas curriculares e em políticas de garantia e avaliação da qualidade do ensino, mas também na progressiva criação de estruturas de apoio à docência (Centros, Núcleos, Gabinetes, Unidades...), localizadas em unidades orgânicas ou centralizadas e apoiadas pelas Reitorias (Vieira, Vieira, Moreira, Silva \& Almeida, 2019). Embora estas estruturas sejam ainda relativamente recentes em Portugal e pouco se conheça sobre a sua atividade, estudos de revisão da literatura situados no contexto internacional têm evidenciado o impacto dos programas de apoio à docência na mudança das culturas pedagógicas nas IES (Chalmers \& Gardiner, 2015; Steinert et al., 2016).

$\mathrm{Na}$ Universidade do Minho, a estrutura com a missão de apoiar a inovação e o desenvolvimento pedagógico é o Centro IDEA-UMinho - Centro de Inovação e Desenvolvimento do Ensino e da Aprendizagem na Universidade do Minho ${ }^{1}$. Este centro foi criado em 2017 pela Reitoria em articulação com a Pró-Reitoria para os Assuntos Estudantis e Inovação Pedagógica² ${ }^{2}$ com os seguintes objetivos:

- Estimular a melhoria do ensino e da aprendizagem;

- Apoiar o desenvolvimento profissional dos docentes;

- Fomentar práticas docentes baseadas na inovação;

1 https://idea.uminho.pt.

$2 \mathrm{O}$ Centro IDEA-UMinho é atualmente coordenado por Manuel João Costa, na qualidade de Pró-Reitor para os Assuntos Estudantis e Inovação Pedagógica, tendo sido anteriormente coordenado por Filipe Vaz e Linda Gonçalves Veiga na mesma qualidade. A equipa é constituída por docentes da UMinho de diversas Unidades Orgânicas, à exceção de Gabriel Hornink, docente da Universidade Federal de Alfenas (Brasil), que se juntou à equipa, em fevereiro de 2020, no âmbito de um estágio científico avançado de pós-doutoramento a decorrer por um ano. 
- Promover e disseminar práticas inovadoras;

- Dinamizar, apoiar e conceber projetos de ensino e aprendizagem;

- Participar em parcerias e redes (multi)disciplinares centradas nas atividades docentes.

Para cumprir estes objetivos, até março de 2020, o centro dinamizou iniciativas de natureza presencial regulares de apoio à docência, com destaque para a formação pedagógica, o apoio à inovação e partilha de experiências e o incentivo à constituição de comunidades de prática. No segundo semestre do ano de 2020, o Centro conheceu um momento ímpar da sua atividade, em resultado da pandemia COVID-19 e dos desafios da transição de emergência para o ensino online. Com a determinação do encerramento das atividades presenciais, a 20 de março de 2020, o Centro assumiu um papel de liderança no apoio à comunidade académica da UMinho, em estreita articulação com o Gabinete de Apoio ao Ensino (GAE3). De março a julho, foi dinamizado um amplo conjunto de açôes que envolveram docentes, estudantes e outros participantes, no sentido de dar resposta a preocupaçôes prementes, num clima de incerteza e urgência. $\mathrm{O}$ presente texto, concluído no final desse primeiro período de transição, apresenta um balanço das ações realizadas, terminando com algumas reflexóes sobre perspetivas de desenvolvimento futuro.

\section{DESAFIOS À TRANSIÇÃO PARA O ENSINO ONLINE}

A pandemia COVID-19 trouxe uma nova realidade ao mundo com impacto em todos os setores, da economia à educação. A sua rápida expansão provocou um salto exponencial dos estudantes afetados pelo encerramento total ou parcial das instituições de ensino, observando-se no início de abril de 2020 um total de 1.7 bilióes de estudantes afetados pela interrupção das atividades presenciais (destes, 1.56 por interrupção total das mesmas), em 193 países (UNESCO, 2020). Esta situação trouxe efeitos para

3 A partir do Despacho RT-44/2020, que apresenta o Regulamento Orgânico das Unidades de Serviços da Universidade do Minho, o GAE passa a designar-se como Núcleo de Apoio ao Desenvolvimento Pedagógico dos Docentes e integra o Serviço de Apoio às Atividades de Educação. 
os relacionamentos interpessoais, elevando o abandono dos estudantes e as desigualdades sociais, além de gerar dificuldades associadas à transição para um ensino remoto emergencial. No final do semestre letivo da UMinho (fim de julho), havia ainda 877 milhões de estudantes afetados, na sua maioria por encerramento completo das atividades presenciais (UNESCO, 2020).

A situação instalou-se em Portugal em meados de fevereiro e, pelo final da primeira semana de março, identificava-se o primeiro caso da doença num estudante da Universidade do Minho. Imediatamente, foi avaliada a situação e aplicado o plano de contingência para evitar novos contágios e conseguir a continuidade das atividades letivas. A indicação de confinamento e encerramento das atividades presenciais ocorreu pouco depois, no dia 8 de março, colocando a academia em grande expetativa sobre o que estaria para vir - o ensino online. $\mathrm{O}$ mesmo foi acontecendo em todas as instituiçóes de ensino portuguesas, gerando um sentimento generalizado de incerteza e instigando mudanças drásticas nos modos de ensinar e aprender nas IES.

Neste contexto, o Centro IDEA-UMinho, juntamente com o GAE e a Pró-reitoria de Assuntos Estudantis e Inovação Pedagógica, assumiu um papel vital para que a transição para o ensino online ocorresse da melhor forma possível num momento de emergência. Essa transição exigia novas atividades de planeamento e desenvolvimento do ensino, incluindo o uso de tecnologias digitais que não faziam parte do quotidiano de todos os professores e estudantes e implicava o desenvolvimento de competências digitais para a educação.

Pensar o ensino online exige um novo olhar sobre os processos de ensino e de aprendizagem e sobre o modo como os instrumentos digitais medeiam esses processos e trazem mudanças nas formas de comunicar e construir conhecimento. Por outro lado, o ensino online requer o acesso de todos os estudantes aos meios digitais de forma a que sejam garantidas condições de equidade na aprendizagem (Santos Jr. \& Monteiro, 2020), assim como um elevado grau de autonomia e autodeterminação por parte dos docentes e estudantes (Castman \& Rodrigues, 2020). 
Em poucas semanas, vários desafios se colocaram à academia:

- Quais as melhores formas de trabalhar em cada área do conhecimento?

- Como escolher as melhores ferramentas digitais?

- Como produzir os materiais digitais educacionais?

- Como quantificar a carga de trabalho e evitar a sobrecarga?

- Como motivar os estudantes à participação?

- Como humanizar as relaçóes no ensino online?

- Como desenvolver e estimular a aprendizagem colaborativa online?

- Como avaliar de forma íntegra, justa e rigorosa?

Estas e outras questôes passaram a fazer parte das preocupaçóes da comunidade e trouxeram um sentido de urgência na procura de soluçôes. Tornou-se evidente a necessidade de promover atividades de formação prioritariamente dirigidas aos docentes, assim como criar redes de suporte, diálogo e colaboração, intrainstitucionais e interinstitucionais.

Procura-se traçar no Quadro 1 o cenário em que foram iniciadas as ações do Centro, a partir de uma análise SWOT sintética (Forças; Fraquezas; Oportunidades; Ameaças). 


\section{Quadro 1. Cenário de transição para o ensino online.}

\section{Fatores (potencialmente) positivos \\ Forças}

- Equipa IDEA capacitada para a formação docente e o uso das tecnologias digitais;

- Gabinete de Apoio ao Ensino com recursos e serviços de apoio ao ensino a distância;

- Plataforma institucional para o ensino e a aprendizagem preparada para atividades de ensino e avaliação online;

- Docentes carenciados de formação para o ensino e avaliação online;

- Sensibilidade dos Conselhos Pedagógicos

e Direçôes de Curso na gestão pedagógica;

- Apoio institucional da Reitoria às iniciativas do Centro-IDEA.

\section{Oportunidades}

- Rentabilização da Plataforma institucional para o ensino e a aprendizagem e meios digitais existentes;

- Exploração de novas tecnologias digitais e desenvolvimento de competências digitais;

- Reconfiguração de práticas pedagógicas (mais centradas nos estudantes);

- Reforço de culturas de colaboração na gestão dos cursos;

- Reforço de parcerias intra/interinstitucionais;

- Orientaçôes emergenciais para o ensino online.

\section{Fatores (potencialmente) negativos Fraquezas}

- Equipa IDEA com número limitado de elementos (não exclusivamente dedicados ao Centro) ${ }^{4}$

- Falta de tradição/experiência generalizada de ensino online na instituição;

- Limitaçóes no acesso de estudantes a equipamentos;

- Limitaçóes de softwares para fins específicos (por ex. para simulação de ambientes laboratoriais ou de contextos profissionais);

- Inexistência de orientaçóes específicas para o ensino online.

\section{Ameaças}

- Potenciais resistência ou dificuldades de mudança pela natureza abrupta e emergencial da transição para o ensino online;

- Isolamento social como obstáculo à colaboração na gestão dos cursos e como fator de desânimo;

- Sobrecarga docente e discente;

- Potenciais dificuldades na gestão do trabalho e estudo remoto;

- Riscos de violação da privacidade dos sujeitos (captação de imagens ou sons de natureza sensível).

A decisão de implementação do ensino online no período de março a julho de 2020 e de uma possível abordagem em blended learning para 2020-2021, representou

4 À exceção de Gabriel Hornink, que participou na planificação, realização e monitorização das atividades do Centro no âmbito do seu estágio científico avançado de pós-doutoramento, desde fevereiro de 2020, trazendo um contributo importante à concretização das ações aqui relatadas. 
um desafio e uma oportunidade para a UMinho, tornando evidente a necessidade de começar a desenvolver condiçóes institucionais facilitadoras da transição para estas modalidades educacionais, aqui definidas por referência a oito eixos de ação indicados pelo European Maturity Model for Blended Education - EMBED

1. Suporte institucional: helpdesk, sítio de suporte, apoio às produçóes;

2. Estratégia institucional/visão educacional: valorização do uso das tecnologias no ensino nas políticas de qualidade da instituição;

3. Partilha e comunidades: criação de condições favoráveis à partilha de experiências e materiais, assim como à constituição de comunidades de prática sustentáveis;

4. Desenvolvimento profissional: fomento de oportunidades para os profissionais se qualificarem e serem reconhecidos por isso na instituição;

5. Garantia da qualidade: implementação de metodologias de avaliação da qualidade que permitam rever e melhorar processos;

6. Governança: revisão de regras, regulamentações e políticas para o ensino a distância (modelos de implementação);

7. Financiamento: alocação de recursos para o desenvolvimento, suporte e estímulo ao uso das tecnologias com fins educacionais;

8. Instalaçôes/infraestrutura: garantia de condiçôes físicas e digitais para a implementação do ensino a distância (por ex., organização diferenciada de salas, sistemas de videogravação, ambientes virtuais de ensino, ferramentas tecnológicas).

As ações desenvolvidas pelo Centro IDEA, apresentadas no ponto seguinte, integram sobretudo aspetos dos eixos 3 e 4 . Contudo, importa sublinhar que a UMinho, tal com as restantes IES portuguesas à exceção da Universidade Aberta, seguem predominantemente um regime de ensino presencial, pelo que as açóes realizadas representaram uma disrupção significativa nas suas práticas, por forma a suceder na transição para um ensino mediado pelas tecnologias digitais.

5 https://embed.eadtu.eu. 


\section{AÇÕES DESENVOLVIDAS PELO CENTRO IDEA-UMINHO}

Antes do início do confinamento, o Centro desenvolvia iniciativas presenciais de formação, partilha de práticas e apoio a projetos, mantendo, para além do seu website $^{6}$, um blogue ${ }^{7}$ para comunidades de prática que o Centro catalisou ao longo da sua existência. A partir da suspensão das atividades presenciais, surgiu imediatamente a necessidade de apoiar os professores e os estudantes na transição para o ensino online através do desenvolvimento de açôes digitais.

Novas formas de comunicação nas redes sociais tomaram corpo com a criação de uma página no Facebook e uma conta no Twitter, canais importantes para a divulgação de recursos e experiências de ensino online que respondiam a necessidades emergentes. Por outro lado, essas necessidades motivaram iniciativas sobre o ensino online, levando à produção e divulgação do boletim IDEAdigital com ideias e recomendaçôes sobre temas diversos e também à dinamização de sessões de formação, com destaque para um conjunto de Webinars, Flipped Webinars e a primeira edição online do curso Docênciat.

Após a conclusão deste curso, criou-se um canal no YouTube para divulgação de vídeos da formação, casos e Webinars, com acesso livre a todos os interessados. Paralelamente a estas açôes, foi criado um espaço informal de diálogo com a academia, Partilhando IDEiAs, com encontros semanais via Zoom, onde foram discutidas temáticas diversas a partir das experiências dos participantes e com o envolvimento de alguns convidados.

O Quadro 2 sintetiza as açóes realizadas, pela ordem cronológica em que foram iniciadas, detalhando-se de seguida o seu desenvolvimento e apresentando alguns dados recolhidos que fornecem indicadores da sua relevância. Estas ações foram planeadas em reuniôes de trabalho semanais da equipa do Centro IDEA com a colaboração do $G A E$, envolvendo parcerias de trabalho com outros docentes, estudantes e estruturas da UMinho e ainda com a Universidade de Aveiro no curso Docênciat.

6 https://idea.uminho.pt.

7 https://cpieauminho.blogspot.com. 
Quadro 2. Síntese das ações do Centro IDEA-UMinho (março a julho de 2020).

\begin{tabular}{|c|c|}
\hline Ações & Descrição \\
\hline $\begin{array}{l}\text { Redes sociais } \\
\text { (Facebook e } \\
\text { Twitter) }\end{array}$ & $\begin{array}{l}\text { Uso das redes sociais (Facebook, Twitter, blog) para } \\
\text { divulgação de iniciativas e indicação de fontes de } \\
\text { apoio ao ensino a distância }\end{array}$ \\
\hline $\begin{array}{l}\text { Boletim } \\
\text { IDEAdigital }\end{array}$ & $\begin{array}{l}\text { Publicação regular de boletins informativos } \\
\text { dirigidos à comunidade académica, para apoio ao } \\
\text { ensino a distância (disponíveis no site do Centro- } \\
\text { IDEA) }\end{array}$ \\
\hline $\begin{array}{l}\text { Partilhando } \\
\text { IDEiAs }\end{array}$ & $\begin{array}{l}\text { Sessões semanais abertas à comunidade académica } \\
\text { semanais (via Zoom), para partilha de experiências } \\
\text { no âmbito do ensino a distância }\end{array}$ \\
\hline $\begin{array}{l}\text { Flipped } \\
\text { webinars }\end{array}$ & $\begin{array}{l}\text { Seminários online dirigidos à comunidade } \\
\text { académica, sobre estratégias e ferramentas de ensino } \\
\text { a distância }\end{array}$ \\
\hline Webinars & $\begin{array}{l}\text { Sessões com temáticas específicas, dinamizadas por } \\
\text { pessoas de conhecimento reconhecido na área }\end{array}$ \\
\hline Docênciat & $\begin{array}{l}\text { 2a edição (julho) de um curso de formação docente, } \\
\text { realizado online em parceria com a Universidade de } \\
\text { Aveiro. A 3 } 3 \text { edição está agendada para setembro }\end{array}$ \\
\hline $\begin{array}{l}\text { YouTube } \\
\text { Docênciat }\end{array}$ & $\begin{array}{l}\text { Canal criado para inserção dos vídeos da formação e } \\
\text { criação de playlists por módulo }\end{array}$ \\
\hline
\end{tabular}

\section{Objetivos}

Divulgação das ações do IDEA e de boas práticas - ponto de comunicação com a comunidade

Atendimento a necessidades de

formação de docentes e estudantes

Abertura ao diálogo com a comunidade, envolvendo docentes e estudantes; partilha e apoio interpares

Formação sobre o uso de ferramentas digitais específicas

Formação em áreas específicas

Formação incidente em blended learning, integrando a planificação de uma unidade curricular para 2020/21

Disseminação das produções audiovisuais do Docênciat

\section{Redes sociais: Facebook e Twitter}

A criação da página no Facebook ${ }^{8}$ e do perfil no Twitter ${ }^{9}$ corresponderam às primeiras açôes do Centro IDEA como estratégia para alcançar um amplo público e disseminar informaçốes, materiais e eventos, assim como fomentar discussões sobre a transição para o ensino online de forma rápida e interativa, em resposta emergencial à situação da pandemia. Embora o recurso às redes sociais ainda encontre alguma resistência nas academias, verifica-se um crescente interesse das instituiçốes pelo seu uso na mudança de formas de comunicação e de relação entre docentes e discentes (Manca,

\footnotetext{
8 http://www.facebook.com/ideauminho.

9 http://www.twitter.com/IdeaUminho.
} 
2019), neste caso incentivado pela situação de confinamento e pela necessidade de fomentar interações virtuais no seio da comunidade académica.

Para uma melhor compreensão de alguns dados que a seguir apresentamos sobre o uso das redes sociais, importa definir alguns termos usados nas estatísticas do Facebook e Twitter:

Posts: Publicações contendo texto com ou sem média;

Tweets: Publicação no Twitter, até 280 carateres, contendo texto com ou sem média; Reações: Indicação de reações de sentimento (gostar, etc.) nas postagens, com ícones; Impressões: Frequência total com que as postagens apareceram nos ecrãs dos usuários; Alcance: Total estimado de usuários que viram alguma das postagens em seu ecrãa, pelo menos uma vez.

Engajamento: Total estimado de usuários que tiveram algum tipo de ação sobre as postagens (clique, reações, compartilhamento, comentário);

Menções: Número de vezes que o nome de um perfil foi mencionado em tweets.

\section{Facebook}

O Facebook (Figura 1) foi utilizado como um canal de divulgação de açôes e materiais, como as sessóes de partilha (Partilhando IDEiAs) e de formação, os boletins IDEAdigital e outros eventos e materiais de terceiros que pudessem ajudar os professores na transição para o ensino online. Colocou a comunidade em contato próximo, alcançando mais de 900 seguidores em poucos meses. 


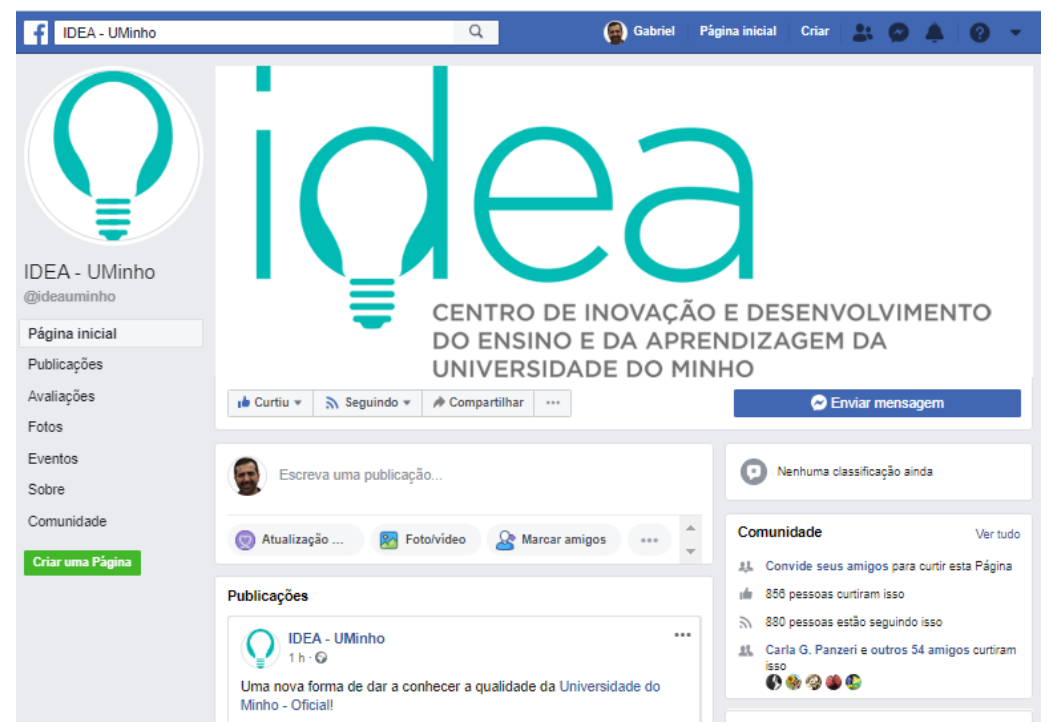

Figura 1. Captura do ecrã com a página de abertura do IDEA no Facebook.

Para caracterizar o uso da página, serão apresentadas algumas estatísticas obtidas no próprio Facebook: Lifetime (total de usuários que 'curtiram' e seguem a página); Visualizaçôes da página; 'Curtidas' na página; Alcance das publicações; Envolvimento com a publicação.

Logo após a sua criação, em apenas dez dias (16 a 26 de março de 2020), a página recebeu 500 novos seguidores, sendo que em 31 de julho havia 971 usuários conectados à página do IDEA. No Gráfico 1 pode observar-se o número total de usuários que 'curtiram' e, consequentemente, seguiram a página (usuários únicos) ao longo do tempo. A grande maioria manteve-se no canal durante os vários meses, indicando um interesse contínuo nas publicações.

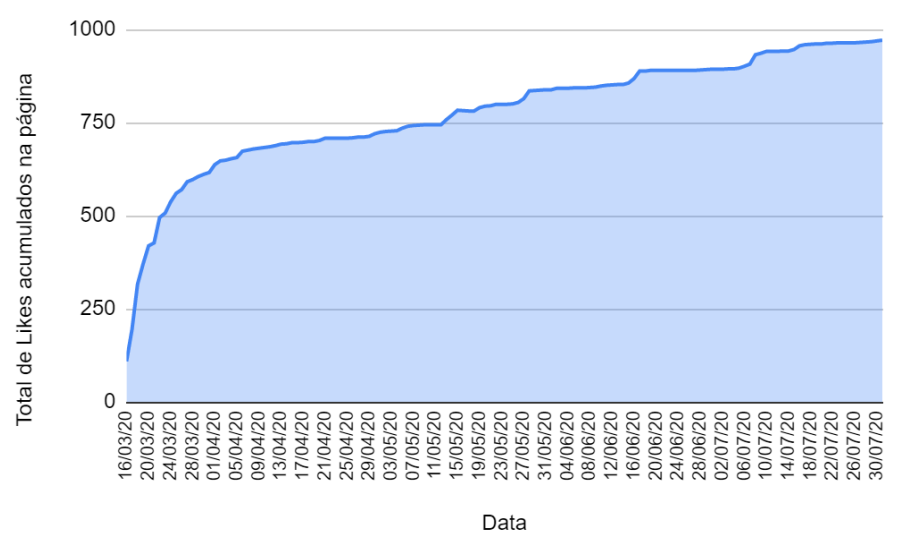

Gráfico 1. Facebook: número total de likes de usuários únicos acumulados. 
O crescimento de usuários indicia a utilidade e importância desse novo canal, juntamente com o número de visualizaçóes, impressóes e engajamento, apresentados na Tabela 1, na qual se destaca o total de likes (quase 1000 seguidores), além de 65.800 impressões, ou seja, o número de vezes que as postagens aparecem no ecrã dos usuários, com um alcance total de 34.543 pessoas. Apesar de ser uma página nova, apresenta dados expressivos e crescentes, reveladores do interesse gerado.

Tabela 1. Likes (seguidores), visualizações, engajamento, impressões e alcance da página no Facebook.

$\begin{array}{lrrrrr}\text { Mês } & \text { Likes } & \text { Visualizações } & \text { Engajamento } & \text { Impressóes } & \text { Alcance } \\ \text { março } & 616 & 1.232 & 1.140 & 11.675 & 5.748 \\ \text { abril } & 720 & 610 & 944 & 13.241 & 7.633 \\ \text { maio } & 838 & 769 & 1.263 & 16.026 & 9.381 \\ \text { junho } & 893 & 444 & 670 & 8.563 & 5.900 \\ \text { julho } & 971 & 1.248 & 1.200 & 16.295 & 5.881 \\ \text { Total } & -- & 4.303 & 5.217 & 65.800 & 34.543 \\ \text { Média } & -- & 861 & 1.043 & 13.160 & 6.909 \\ \text { Desvio } & -- & 365 & 241 & 3.217 & 1.586 \\ \text { Padrão } & - & & & & \end{array}$

A partir dos registos de likes identificaram-se acessos de 23 países, sendo que 73.0\% dos usuários eram de Portugal, 21.3\% do Brasil e os demais (5.7\%) distribuíram-se por 21 países (Espanha, Tadjiquistão, Moçambique, Rússia, Tailândia, Chile, Holanda, Roménia, Estados Unidos, Canadá, Suíça, Alemanha, Dinamarca, França, Reino Unido, Itália, México, Peru, Suécia, Tunísia, Turquia). Relativamente às cidades, identificaram-se acessos em 103 cidades, destacando-se Braga (37,1\%), Porto (8.4\%), Guimarães (6.4\%), Lisboa (4.8\%) e Alfenas-Brasil (2.76\%).

O gráfico 2 permite uma análise mais detalhada dos mesmos dados, apresentando o total de usuários únicos que acessaram a página diariamente. Observa-se um elevado número de visualizaçóes iniciais, feitas pelo primeiro grande número de usuários, 
observa-se depois uma flutuação nas visualizaçôes, correspondendo aos momentos com postagens na página, com 31 visualizações em média, um desvio padrão de 45, máximo de 383 e mínimo de 1 . Destaca-se o maior pico no dia 8 de julho (387), o qual corresponde ao dia de um webinar de Roni Roberts (Universidade de Exeter) sobre o envolvimento dos estudantes, promovido pelo IDEA e transmitido pelo Facebook e Zoom (simultaneamente).

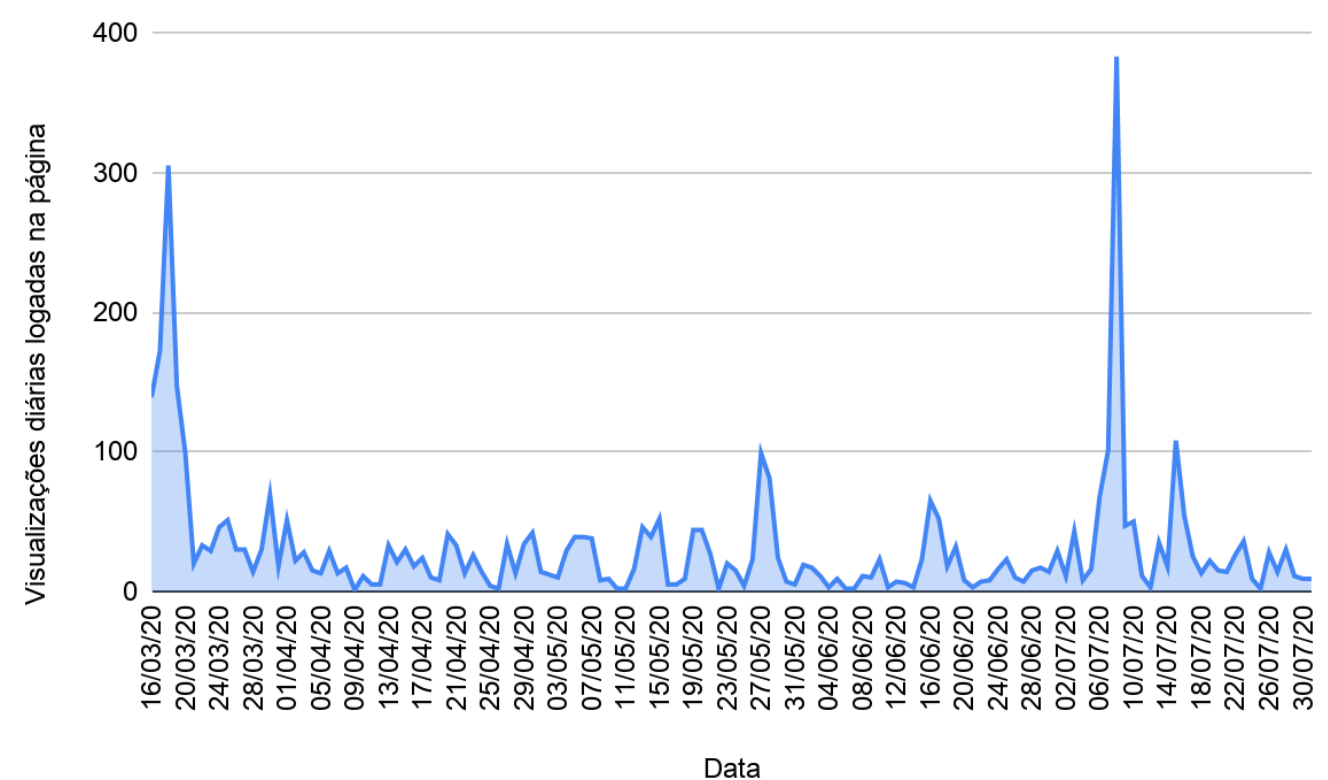

Gráfico 2. Facebook: frequência total diária de visualizaçóes.

O Gráfico 3 apresenta o alcance das publicações, correspondente ao número estimado pelo Facebook de pessoas que viram no seu ecrã, pelo menos uma vez, qualquer uma das publicações, check-in em eventos ou partilhas com origem na página do $I D E A$. O gráfico indica o total diário por usuários únicos. É possível que um mesmo usuário veja mais do que uma publicação da página no mesmo dia, mas contará apenas uma vez no alcance. Estes dados são um indicador positivo da divulgação das ações do IDEA, havendo 280 usuários únicos alcançados em média diária no período indicado no gráfico, com um desvio padrão de 294, máximo de 2.234 (dia do Webinar de Roni Roberts) e mínimo de 1 . Destacam-se, pelo menos, quatro picos acima de 1000 e 16 picos acima de 500, o que representa um bom alcance para uma página educacional em início de atividade nas redes sociais. 


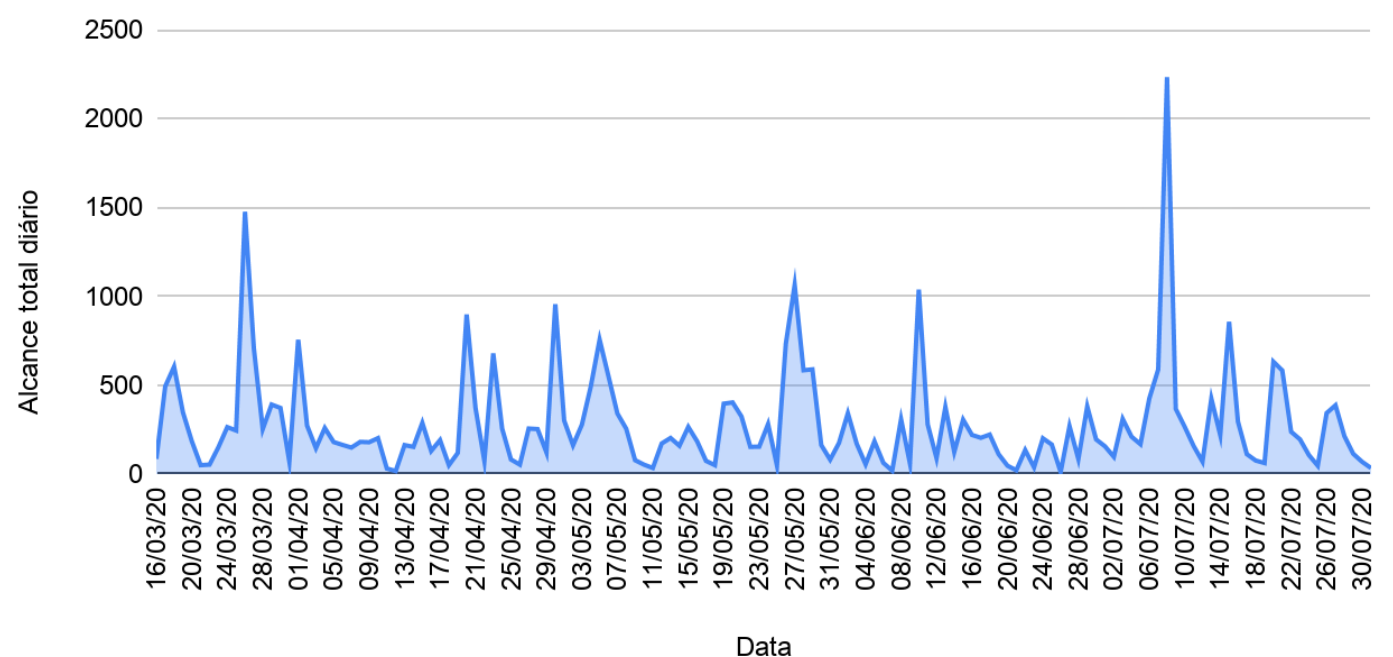

Gráfico 3. Facebook: alcance diário total de engajamento na página por usuários únicos.

Diferentemente do alcance, o número de impressões traz a frequência total de visualizaçôes de um conteúdo da página. Um mesmo usuário pode gerar apenas um alcance e várias impressóes, sendo de esperar que as frequências de impressão sejam superiores às de alcance. Apresentamos no Gráfico 4 o total de impressóes diárias, o que inclui o total de visualizações no ecrã de alguma postagem, check-in e outras informações da página. Os dados são expressivos, com 478 impressóes em média diária, um desvio padrão de 479, máximo de 3696 (dia do Webinar do Roni Roberts) e mínimo de 25, destacando-se oito picos acima de 1000.

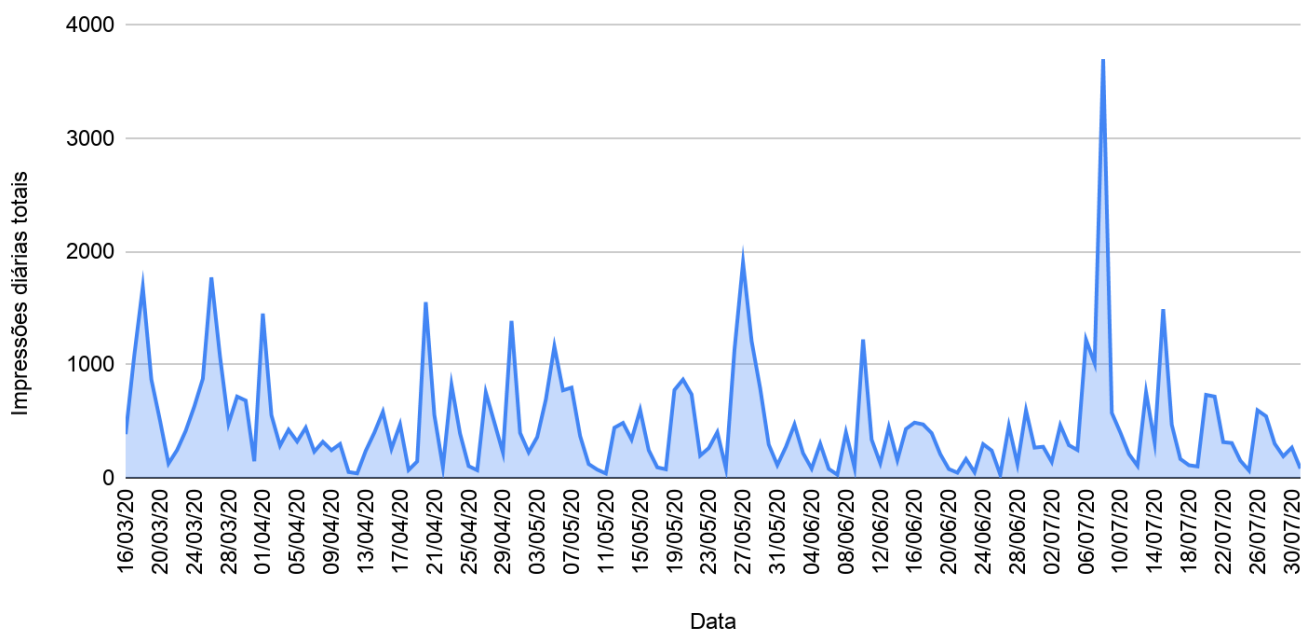

Gráfico 4. Facebook: total de impressóes diárias na página. 
Para sabermos se o alcance foi efetivo e se essas visualizações foram do interesse dos usuários, é importante observar os dados do engajamento, ou seja, se houve reaçôes às postagens. O número de engajamentos corresponde ao número estimado, pelo Facebook, do total de açôes dos usuários face às publicações da página, como um like/dislike, uma partilha, um comentário ou uma reação (ex., gostei). O Gráfico 5 apresenta as frequências diárias de engajamento, sendo que no período abrangido houve 38 em média diária, com desvio padrão de 41, máximo de 245 e mínimo de 1 , destacando-se 9 picos acima de 100 e 28 acima de 50 (maior engajamento novamente no dia do Webinar de Roni Roberts). É interessante ressaltar que o gráfico do alcance acompanha o gráfico do engajamento, ou seja, a visualização das postagens gerou algum tipo de reação nos usuários, o que é outro indício do interesse e, possivelmente, da importância dessas postagens para as pessoas. Destaca-se que, ao longo do período avaliado, houve somente uma reação de ocultar conteúdo, na qual o usuário solicita que aquela postagem ou tipo de postagem não apareça mais, o que reforça os indícios do interesse pelas publicações do IDEA.

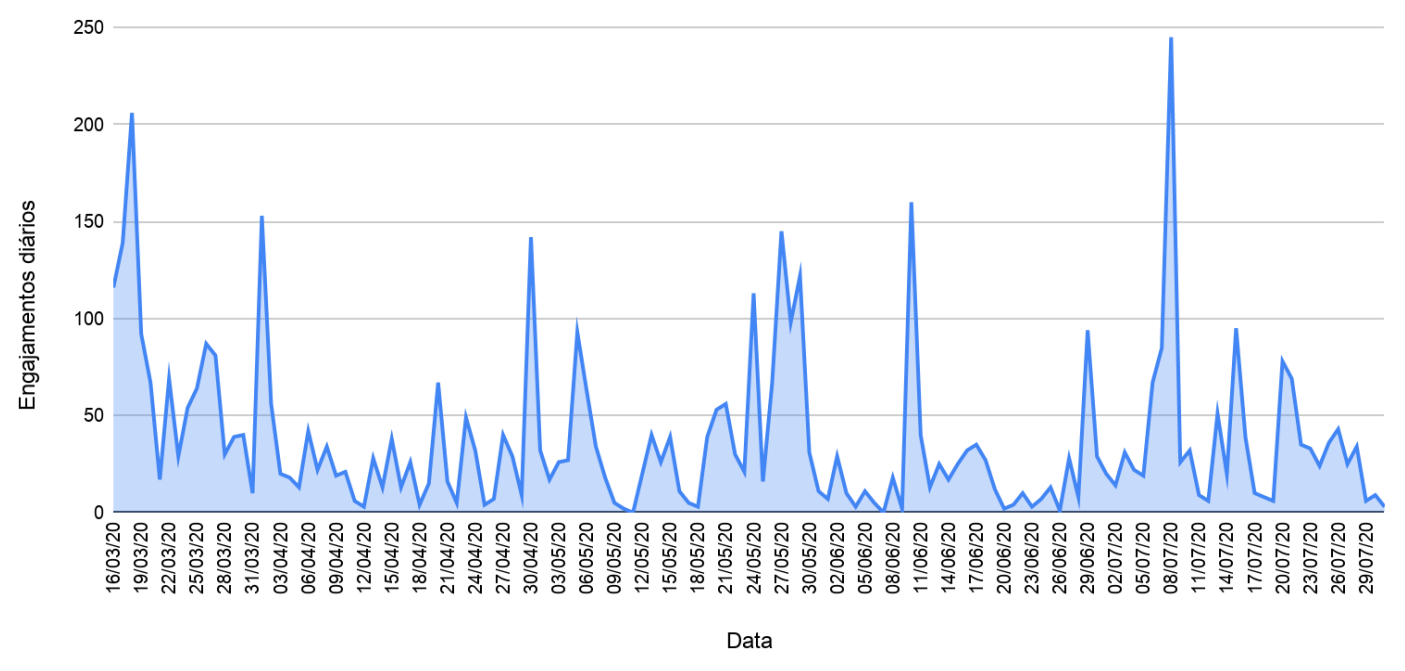

Gráfico 5. Facebook: frequências diárias de engajamentos por usuários únicos.

As postagens com maior alcance e engajamento foram as que envolviam atividades do $I D E A$, como foi o caso da postagem de divulgação da construção do curso de formação Docência + em conjunto com a Universidade de Aveiro. Esta postagem obteve um alcance de 1.646 pessoas, 248 cliques e 87 reaçóes (335 engajamentos no 
total). Outro destaque ocorreu com a divulgação de uma das sessões do partilhando IDEiAs, a qual foi motivada pela iniciativa "Skills 4 pós-COVID - Competências para o futuro", abordando os desafios e oportunidades para a Universidade no contexto da retoma da atividade letiva. Nessa postagem, acredita-se que houve um grande interesse da comunidade académica em saber o que aconteceria na retoma do semestre, gerando um alcance de 1.216 pessoas, com um total de 33 engajamentos. Corroborados os dados anteriores, a transmissão do Webinar de Roni Roberts teve o maior alcance da página no período (2494). Percebe-se que há maior engajamento quando as pessoas veem maior utilidade na postagem ou se veem como parte da postagem, o que agrega um valor afetivo às reações e estimula o envolvimento na página do $I D E A$.

\section{Twitter}

Não sendo a rede social mais usada em 2020, o Twitteré uma ferramenta ainda utilizada por muitos docentes e estudantes. Assim, a par da criação da página no Facebook, criou-se o perfil @IdeaUminho (Figura 2), como estratégia para ampliar a divulgação e aumentar o alcance e engajamento da comunidade.

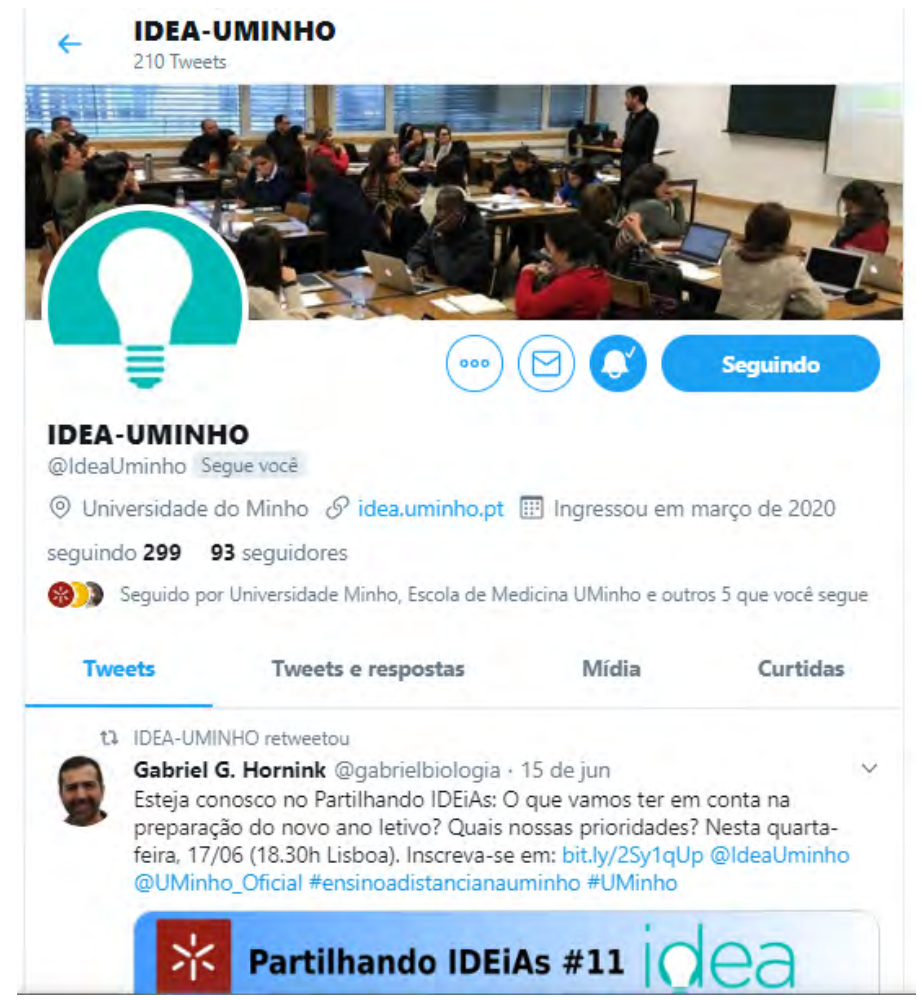

Figura 2. Captura do ecrã com a página de abertura do IDEA no Twitter. 
As postagens no Twitter (tweets) surgiram nas páginas das pessoas que seguem o perfil do IDEA, sendo os seguidores, inicialmente, indicados por convite. Os seguidores passam a 'curtir' os tweets, a comentar e a 'retweetar', ou seja, as pessoas que seguem quem fez o retweet passam a ver a postagem do IDEA e podem seguir o perfil. Dessa forma, foi possível a expansão para 112 seguidores (31/07/2020). Além disso, o perfil do IDEA pode seguir outros usuários (378 na mesma data) e assim manter-se atualizado e selecionar o que for interessante para 'retweetar' no próprio perfil, formando-se progressivamente uma rede social de comunicações e colaboraçóes. A partir da ferramenta de análise do Twitter $^{10}$, obtivemos o total de tweets, visitas ao perfil, impressóes dos tweets, menção e seguidores ( 16 de março a 31 de julho). Similarmente ao Facebook, entende-se o número de impressóes como o número de vezes que um tweet apareceu na tela de um usuário. A Tabela 2 apresenta os valores mensais das principais estatísticas, destacando-se o total de 33.380 impressóes e 1201 engajamentos.

Tabela 2. Síntese dos dados estatísticos do Twitter Analytics.

$\begin{array}{lrrrrrr}\text { Mês } & \text { Tweets } & \text { Impressóes } & \text { Engajamento } & \begin{array}{r}\text { Visitas ao } \\ \text { perfil }\end{array} & \text { Menções } & \begin{array}{r}\text { Novos } \\ \text { seguidores }\end{array} \\ \text { março } & 24 & 5.072 & 164 & 325 & 13 & 29 \\ \text { abril } & 37 & 7.276 & 248 & 269 & 49 & 30 \\ \text { maio } & 28 & 5.931 & 257 & 136 & 27 & 15 \\ \text { junho } & 29 & 7.692 & 193 & 171 & 17 & 23 \\ \text { julho } & 26 & 7.409 & 339 & 215 & 10 & 15 \\ \text { Soma } & 144 & 33.380 & 1.201 & 1.116 & 116 & 112 \\ \text { Média } & 30 & 6.493 & 216 & 225 & 27 & 24 \\ \text { DP } & 5 & 1.209 & 44 & 87 & 16 & 7\end{array}$

10 https://analytics.twitter.com. 
Apesar de os dados não serem tão expressivos como os do Facebook, o que era de esperar por ser uma plataforma com menor utilização, apresentou um valor elevado de impressóes para o número de seguidores. Tal como no Facebook, as postagens com notícias de ações do $I D E A$ e com alguma indicação de ação futura tiveram maior impacto, como foi o caso da notícia sobre a formação Docência + (768 impressões), a postagem sobre a apresentação de experiências pelos estudantes durante esse curso (628 impressões) e a divulgação da live de abertura do curso (860 impressões).

\section{Boletim IDEAdigital}

O boletim IDEAdigital ${ }^{11}$ é uma publicaçãoo regular de apoio ao ensino no espaço digital, dinamizada pela equipa do Centro com diversas colaborações (docentes, estudantes, Gabinete Para a Promoção da Inclusão, Desenvolvimento e Sucesso dos Estudantes), iniciada uma semana após o encerramento das aulas presenciais. A primeira edição teve lugar em 16/03/20, tendo sido produzidos 20 textos (Quadro 3) maioritariamente dirigidos aos docentes, sobre estratégias para o ensino online, recursos digitais e produção de materiais digitais, gestão do estudo e trabalho online, e avaliação online. Foram também publicadas algumas sínteses de sessões Partilhando IDEiAs.

Foi usado o Google Drive para a construção dos boletins a partir de um template, envolvendo autores e editores num regime de parceria e escrita colaborativa. A partir do boletim 17 introduziu-se a colaboração permanente de estudantes na autoria e edição dos textos, em parceria com a AAUM (Associação Académica da Universidade do Minho), de forma a trazer a sua visão para a construção dos materiais. A produção dos boletins exigiu um grande esforço no sentido de manter a sua regularidade e dar resposta a necessidades prementes da academia.

11 https://idea.uminho.pt/ideadigital/Paginas/Blogue.aspx 
Quadro 3. Boletim IDEAdigital.

$\begin{array}{lll}\text { Título } & \text { Público } & \text { Data } \\ \text { \#1 Ensinar online... como? } & \text { Docentes } & 16 / 03 \\ \text { \#2 Moderar atividades online em direto } & \text { Docente } & 20 / 03 \\ \text { \#3 Aulas digitais em formato assíncrono } & \text { Docente } & 26 / 03 \\ \text { \#4 Apoio ao trabalho assíncrono dos estudantes } & \text { Docente } & 01 / 04 \\ \text { \#5 TBL a distância na Blackboard } & \text { Docente } & 06 / 04 \\ \text { \#6 Partilhando IDEiAs \#1 } & \text { Amplo } & 13 / 04 \\ \text { \#7 Construir um teste/exame de consulta } & \text { Docentes } & 14 / 04 \\ \text { \#8 Testes/exames de consulta - estudantes } & \text { Estudantes } & 14 / 04 \\ \text { \#9 Partilhando IDEiAs \#2 } & \text { Amplo } & 16 / 04 \\ \text { \#10 Partilhando IDEiAs \#3 } & \text { Amplo } & 20 / 04 \\ \text { \#11 Recursos focados nos estudantes } & \text { Docentes } & 22 / 04 \\ \text { \#12 Métodos de avaliação alternativos } & \text { Docentes } & 22 / 04 \\ \text { \#13 Partilhando IDEiAs \#4 } & \text { Amplo } & 28 / 04 \\ \text { \#14 Gestão do trabalho a distância } & \text { Amplo } & 30 / 04 \\ \text { \#15 Conteúdos digitais acessíveis: diretrizes gerais } & \text { Docentes } & 15 / 05 \\ \text { \#16 Conteúdos digitais acessíveis: especificaçóes para } & & \\ \text { formatos e conteúdos } & \text { Docentes } & 15 / 05 \\ \text { \#17 Boas práticas para a realização de testes ou exames } & & \\ \text { online } & \text { Estudantes } & 20 / 05 \\ \text { \#18 Repositórios digitais } & & \\ \text { \#19 Medidas de apoio ao processo de avaliação dos } & \text { Amplo } & 28 / 05 \\ \text { estudantes com Necessidades Educativas Especiais } & \text { Docentes } & 05 / 06 \\ \text { \#20 Ferramentas digitais } & \text { Amplo } & 18 / 06\end{array}$

\section{Partilhando IDEiAs}

A transição abrupta para o ensino a distância, a par da perda do contacto face a face, gerou uma situação inédita de isolamento que motivou o Centro IDEA a criar um espaço informal de diálogo no Zoom, aberto à academia. Assim, três semanas após encerramento das atividades presenciais, surgiu a iniciativa Partilhando IDEiAs ${ }^{12}$, concretizada em sessóes temáticas semanais realizadas às quartas-feiras ao final da tarde, com o objetivo

12 https://idea.uminho.pt/pt/ideadigital/Paginas/Partilhando-IDEAs.aspx. 
de promover a partilha de ideias e experiências a partir das vivências dos participantes. Após uma breve introdução plenária, o tema da sessão era discutido em salas de discussão (breakout rooms) moderadas por elementos do IDEA e outros colegas que colaboraram nesta tarefa, nomeadamente docentes das comunidades de prática anteriormente constituídas em articulação com a atividade do Centro. O papel dos moderadores era mediar o diálogo, incentivar a participação e anotar ideias principais que depois partilhavam em plenário na fase final das sessões. O número médio de participantes nas 12 sessões realizadas (Quadro 4) foi de 94 (mínimo de 52 e máximo de 142), maioritariamente docentes. As sessóes 5 e 12, onde participaram os Reitores da UMinho e da Universidade de Aveiro, foram conduzidas em plenário.

Quadro 4. Sessões Partilhando IDEiAs.

\begin{tabular}{|c|c|c|c|}
\hline Sessões & Data & Participantes & Moderadores \\
\hline $\begin{array}{l}\text { 1. As experiências dos professores e dos estudantes na aula } \\
\text { virtual }\end{array}$ & $01 / 04$ & 68 & 9 \\
\hline 2. A estruturação da avaliação à distância & $08 / 04$ & 142 & 16 \\
\hline 3. A avaliação formativa à distância & $15 / 04$ & 66 & 11 \\
\hline 4. Experiências com a avaliação sumativa à distância & $22 / 04$ & 52 & 13 \\
\hline $\begin{array}{l}\text { 5. O ensino na Universidade do Minho em 2021: Como } \\
\text { preparar, como cuidar? (Reitor) }\end{array}$ & $29 / 04$ & 96 & -- \\
\hline $\begin{array}{l}\text { 6. Como apoiar os docentes na preparação de atividades } \\
\text { letivas para 2020/2021? }\end{array}$ & $06 / 05$ & 113 & 12 \\
\hline $\begin{array}{l}\text { 7. Como envolver mais e melhor os estudantes nas } \\
\text { experiências de ensino remoto? }\end{array}$ & $13 / 05$ & 72 & 9 \\
\hline $\begin{array}{l}\text { 8. O que aprendemos sobre realizar avaliações online } \\
\text { (presidentes dos Conselhos Pedagógicos) }\end{array}$ & $20 / 05$ & 94 & 10 \\
\hline $\begin{array}{l}\text { 9. O ensino na Universidade do Minho em 2021: Como } \\
\text { preparar, como cuidar? }\end{array}$ & $27 / 05$ & 104 & 11 \\
\hline $\begin{array}{l}\text { 10. Avaliação da qualidade do ensino e estruturas } \\
\text { pedagógicas no contexto da pandemia: que desafios e que } \\
\text { oportunidades? (vice-reitor para qualidade) }\end{array}$ & $03 / 06$ & 64 & 5 \\
\hline $\begin{array}{l}\text { 11. O que vamos ter em conta na preparação do novo ano } \\
\text { letivo? }\end{array}$ & $17 / 06$ & 127 & 11 \\
\hline $\begin{array}{l}\text { 12. À conversa com os reitores das Universidades de } \\
\text { Aveiro e do Minho sobre o próximo ano letivo }\end{array}$ & $01 / 07$ & 128 & -- \\
\hline
\end{tabular}


No final da quarta sessão, foi lançado um questionário de opinião aos participantes para obter as suas perceções sobre a utilidade da iniciativa. Responderam 38 pessoas ( $86 \%$ professores e $14 \%$ estudantes), sendo a maior parte da UMinho (84\%) e algumas de IES portuguesas (4\%) e de outros países (2\%). Numa escala de 1 (Nada útil) a 5 (Muito útil), $53 \%$ assinalaram o ponto 5 e 39\% assinalaram o ponto 4, o que indica uma perceção positiva da utilidade da iniciativa. O questionário apresentava uma lista de possíveis motivos de interesse pela iniciativa, que podiam ser assinalados livremente, obtendo-se o resultado apresentado na Tabela 3, onde se destaca o facto de as sessóes representarem um espaço de partilha e de reflexão. De facto, o que se observava durante as sessôes era a predisposição dos participantes para ouvirem e serem ouvidos, para partilharem preocupaçôes, vivências e práticas experimentadas, o que parecia contribuir para um ambiente produtivo de reflexão na procura de soluções para os problemas enfrentados, encarados como problemas comuns e não individuais.

Tabela 3. Perceçóes de utilidade da iniciativa Partilhando IDEiAs.

\section{Motivo para ter gostado da iniciativa}

Espaço para partilhar as minhas ideias e experiências

Espaço para ouvir as ideias e experiências de outros

Abordagem de temáticas relacionadas com meu quotidiano

Momento para refletir sobre o ensino online

Organização em pequenas salas para partilha

Conhecer ferramentas para o ensino online

Outros

$$
\begin{array}{r}
\% \\
45,9 \% \\
94,6 \% \\
45,9 \% \\
73,0 \% \\
45,9 \% \\
62,2 \% \\
5,4 \%
\end{array}
$$

No questionário solicitavam-se também sugestões de temas para sessões futuras, surgindo ideias focadas nos seguintes eixos: planeamento para o futuro; gestão de turmas de grande dimensão; gestão do trabalho docente; promoção da participação dos estudantes; proteção de dados; avaliação online. Estes e outros assuntos foram sendo discutidos ao longo das sessóes seguintes, num clima de abertura e sinceridade, concluindo-se que esta iniciativa foi essencial para criar um sentido de comunidade nas circunstâncias adversas em que todos vivíamos. 
Um dos pontos a destacar nesta iniciativa foi a presença e participação de estudantes. Embora em número reduzido, traziam para as sessóes a voz da comunidade estudantil, as suas vivências, preocupações e sugestóes no processo de transição para o ensino online, o que foi muito enriquecedor para o grupo. Outro aspeto a referir foi a participação de colegas de outras IES, principalmente da região norte do país, assim como de outros países de língua portuguesa. Finalmente, importa destacar a presença de elementos das estruturas de gestão, em particular os presidentes dos Conselhos Pedagógicos da UMinho e membros das Reitorias da UMinho e da Universidade de Aveiro, contribuindo para estreitar o diálogo entre gestores e docentes sobre problemas que afetavam toda a academia e para as quais importava encontrar soluçóes concertadas.

\section{Formação: Flipped webinars, Webinars e curso Docência+}

As necessidades e interesses de formação no âmbito de metodologias ativas e tecnologias digitais aumentaram à medida que a pandemia se expandia e o isolamento aumentava, mostrando que no horizonte futuro se desenhava a possibilidade de continuidade do ensino online ou a aplicação de modelos híbridos de ensino (blended learning). No âmbito da formação docente em ambientes virtuais, o Centro dinamizou as seguintes iniciativas: Flipped Webinars, Webinars e o curso Docência + em colaboração com a Universidade de Aveiro. Apresentamos cada uma delas em seguida.

\section{Flipped webinars}

Ainda na primeira fase do isolamento (cerca de um mês depois), foram organizados flipped webinars para ilustrar o uso de algumas tecnologias e metodologias ativas, selecionadas em função da sua aplicabilidade imediata pelos docentes nas suas unidades curriculares, indo dessa forma ao encontro das suas necessidades e disseminando boas práticas já desenvolvidas na UMinho. Os inscritos acediam a um vídeo curto sobre o uso da ferramenta em questão, previamente disponibilizado, e participavam posteriormente numa sessão síncrona de 1 hora, na qual os dinamizadores apresentavam o uso real das ferramentas em determinadas unidades curriculares, para que os docentes pudessem refletir sobre esse uso e dialogar sobre como poderiam transpô-lo para os seus próprios contextos de ensino. 
Entre 20 de abril e 06 de maio decorreram as primeiras ediçóes dos flipped webinars $^{13}$ e a segunda oferta ocorreu entre 06 e 10 de julho, paralelamente ao curso Docência+ (06 - 17 de julho), somando um total de 25 sessões de formação e 881 inscritos, com as temáticas apresentadas no Quadro 5.

Quadro 5. Flipped Webinars.

\begin{tabular}{|c|c|c|c|c|c|}
\hline Título & Oferta & Sessões & Inscritos & $\begin{array}{l}\text { Badges } \\
\text { Julho }\end{array}$ & Dinamizadores \\
\hline $\begin{array}{l}\text { ARS: Audience Response System } \\
\text { (VoxVote e Mentimeter) em sessões } \\
\text { síncronas }\end{array}$ & abril e julho & 4 & 171 & 60 & $\begin{array}{l}\text { Cacilda Moura, } \\
\text { Joaquim Silva, } \\
\text { Rui Oliveira }\end{array}$ \\
\hline $\begin{array}{l}\text { Como construir um mural virtual de } \\
\text { aprendizagem colaborativa com recurso } \\
\text { ao Padlet }\end{array}$ & abril & 5 & 146 & 57 & Sílvia Araújo \\
\hline $\begin{array}{l}\text { Como promover aulas em TBL à } \\
\text { distância }\end{array}$ & abril e julho & 5 & 175 & 89 & $\begin{array}{l}\text { Elsa Costa e } \\
\text { Silva, Eugénia } \\
\text { Ribeiro, Teresa } \\
\text { Freire }\end{array}$ \\
\hline $\begin{array}{l}\text { Construção de mapas conceituais } \\
\text { online (CMap Tools) }\end{array}$ & abril & 2 & 22 & --- & $\begin{array}{l}\text { Gabriel Gerber } \\
\text { Hornink }\end{array}$ \\
\hline Google drive: Escrita colaborativa & abril & 2 & 16 & --- & $\begin{array}{l}\text { Gabriel Gerber } \\
\text { Hornink }\end{array}$ \\
\hline PerusALL & abril e julho & 3 & 146 & 71 & $\begin{array}{l}\text { Pedro B. } \\
\text { Albuquerque }\end{array}$ \\
\hline $\begin{array}{l}\text { Ted-Ed: Reciclar conteúdos disponíveis } \\
\text { na web, usar vídeos YouTube }\end{array}$ & abril e julho & 4 & 205 & 58 & $\begin{array}{l}\text { Manuel João } \\
\text { Costa }\end{array}$ \\
\hline
\end{tabular}

Destaca-se que a oferta que ocorreu simultaneamente ao programa Docência+ teve grande procura por parte dos inscritos no curso, apesar de os webinars serem opcionais à formação, sendo que na avaliação final do evento, numa escala de 1 (nada relevante) a 5 (totalmente relevante), 62 dos respondentes (47,3\%) assinalaram o ponto 5 e $47(35,9 \%)$ assinalaram o ponto 4, ou seja, a maior parte considerou os flipped webinars relevantes para sua formação. Percebeu-se, durante as formações, o interesse dos

13 https://idea.uminho.pt/pt/ideadigital/Paginas/Flipped-webinar.aspx. 
participantes em saber mais sobre as temáticas abordadas e como as integrar no contexto que estavam a vivenciar, sendo mais um indicador de que a ação teve bons resultados. A partir da segunda oferta, deu-se a possibilidade aos participantes de se registarem para receber uma microcredencial digital, na forma de open badges, para certificar a sua participação na formação, sendo uma forma de estímulo e reconhecimento aos participantes.

\section{Webinars}

Algumas necessidades pontuais e cruciais ao desenvolvimento do ensino online exigiram uma outra iniciativa do centro, os Webinars IDEA, na qual foi possível trazer especialistas em áreas como a avaliação online e a participação discente no planeamento das UC.

O primeiro webinar (22 de abril) incidiu em métodos alternativos de avaliação e foi apresentado pela Professora Geraldine O’Neill (University College Dublin-U. $\mathrm{CD}$, Ireland), sendo transmitido no Zoom. A dinamizadora partilhou a sua experiência no ensino superior na Irlanda, sugerindo algumas ferramentas digitais e processos para enfrentar os desafios causados pelas circunstâncias da pandemia, abordando formas alternativas de avaliação e a questão da integridade académica, e apresentando recursos da UCD e do "National Forum for the Enhancement of Teaching and Learning". O webinar ${ }^{14}$ contou com 113 participantes, os quais puderam dialogar com Geraldine O’Neill num momento importante, próximo da realização dos exames, quando os professores estavam particularmente preocupados sobre como os realizar online. Na nuvem de palavras criada a partir do chat da sessão, apresentada na Figura 3, na qual se destacam as palavras students, feedback, assessment, exames, evaluation e online, o que reflete, de certa forma, o foco da sessão no estudante e em estratégias de avaliação formativa a distância.

$14 \underline{\text { https://idea.uminho.pt/pt/ideadigital/Paginas/Flipped-webinar.aspx. }}$. 


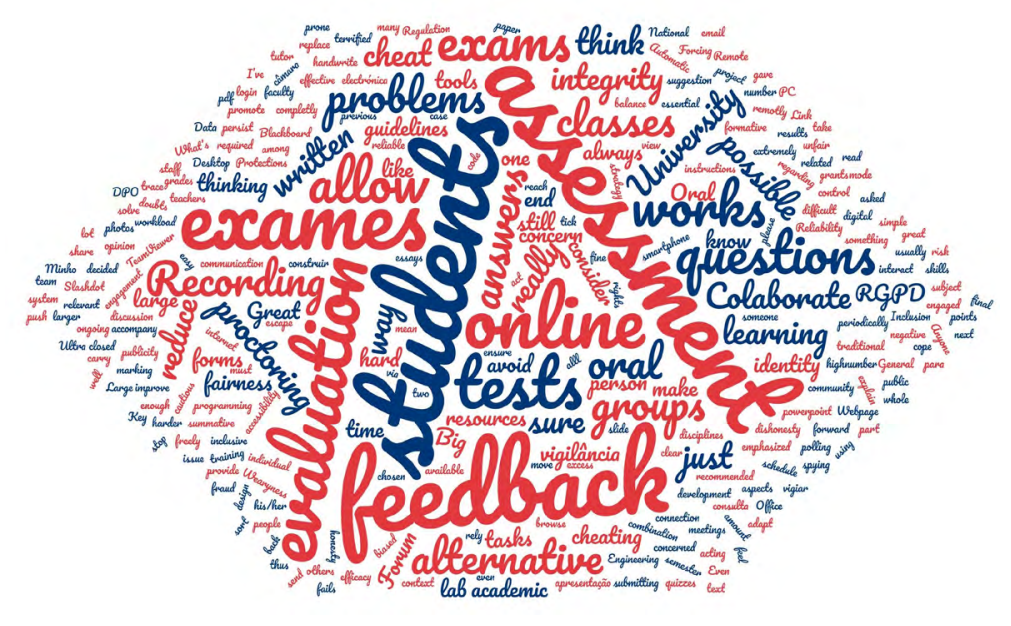

Figura 3. Nuvem de palavras (chat do webinar de Geraldine O’Neil).

A partir desta sessão produziu-se o boletim \#12 $2^{15}$, o qual apresenta uma hiperligação para a gravação da apresentação e os slides utilizados, o que permitiu o acesso à atividade para quem não pôde estar presente. Somente pelo controle do Bitly ${ }^{16}$, verificaram-se 248 downloads, sem contar os downloads pelo link direto do sítio do IDEA e pessoas que replicaram esse link. Assim, consideramos que foi uma atividade de grande alcance e que foi ao encontro dos interesses dos docentes.

O segundo webinar (08 de julho) foi apresentado pelo Doutor Roni Roberts (University of Exeter), abordando os estudantes como pares e condições para estimular o seu envolvimento mais efetivo na melhoria da sua experiência. Este webinar foi transmitido no Zoom e na página do Facebook do $I D E A^{17}$, sendo uma das atividades complementares oferecidas durante a formação Docência +, aberta à comunidade externa. Como vimos atrás, esta atividade resultou nos maiores valores de engajamentos, impressão e alcance na página do Facebook (dados na sessão facebook), indicando a sua relevância e o grande interesse pela temática abordada.

O terceiro webinar (15 de julho) focou as questóes da inclusão na universidade (A docência e o desafio da inclusão: práticas na UA e na UMinho), sendo dinamizado

15 https://idea.uminho.pt/pt/ideadigital/entradas/Paginas/entrada12.aspx.

16 https://bit.ly.

17 https://www.facebook.com/watch/live/?v=299608428080444\&ref=watch_permalink. 
por Alexandra Queirós (Vice-Reitora da Universidade de Aveiro) e Manuel João Costa (Pró-Reitor da UMinho), com intervençôes de Gracinda Martins (Gabinete Pedagógico), Carlos Barbosa (Núcleo de Promoção da Inclusão, Desenvolvimento e Sucesso dos Estudantes da UMinho) e, ainda, de Joaquim Alvarelhão (Escola Superior de Saúde da Universidade de Aveiro) e Carla Sá (Escola de Economia e Gestão da UMinho). Este webinar foi também transmitido pelo Zoom e na página do Facebook do IDEA ${ }^{18}$.

A questão da inclusão é um grande desafio no ensino presencial, sendo que a transição para o ensino online traz novos desafios, uma vez que o uso de meios digitais elimina muitos elementos que são importantes para atender a diversas necessidades, exigindo novas ferramentas. Nesse sentido, será importante avaliar cada caso e potenciar os meiosdigitais que melhor respondam a necessidades específicas. Destaca-se que a equipa do Núcleo de Promoção da Inclusão, Desenvolvimento e Sucesso dos Estudantes da UMinho esteve envolvida na produção de três boletins do IDEAdigital, no sentido de auxiliar os docentes na produçãode materiais digitais acessíveis, assim como na implementação de medidas para apoiar o processo avaliativo dos estudantes com necessidades educativas especiais.

\section{Docência+}

Para fechar o ciclo de atividades do Centro IDEA e trazer um contributo significativo à formação docente para a implementação do modelo blended learning no ano letivo 2020/2021, foi dinamizado o curso de formação online Docênciat, em parceria com o Núcleo de Ensino Aprendizagem do Gabinete do Reitor da Universidade de Aveiro, que decorreu de 6 a 17 de julho de 2020. A iniciativa deu continuidade à sua primeira edição em 2019, realizada presencialmente e organizada pelo Centro IDEA sob a forma de um retiro de 3 dias na Casa Museu de Monção, com participantes da UMinho e da Universidade de Aveiro. Na mensagem de boas-vindas da equipa do Centro então deixada no programa do curso, podia ler-se o seguinte:

18 https://wwwfacebook.com/watch/live/?v=302549817770468\&ref=watch permalink. 
Mais do que um curso sobre a inovação nos processos de ensino-aprendizagem no ensino superior, o Docência + procura constituir um espaço de reflexão, partilha e colaboração entre pares, com a finalidade de darmos maior sentido à nossa atividade de ensino e à atividade de aprendizagem dos nossos estudantes.

Reconhecendo que cada um de nós tem a sua história, as suas aspiraçôes e ideais profissionais, mas também que a mudança pedagógica nas universidades não pode ser um caminho isolado e solitário, o Docência + valoriza a pluralidade de ideias e práticas na construção de projetos de inovação que respeitem a autonomia pedagógica de cada um e que, em simultâneo, se afigurem relevantes à configuração de cenários de mudança mais coletivos, e portanto mais solidários e sustentáveis. (Dossiê introdutório ao curso, p.4)

A segunda edição do curso partia destes mesmos pressupostos e o grande desafio foi a sua programação para um regime de formação em e-learning. Por outro lado, desta vez um dos focos centrais da formação era o blended learning, na medida em que este seria o regime de ensino previsto para o ano letivo de 2020-2021.

Tal como na edição anterior, o curso integrou o desenvolvimento de um projeto que consistia no planeamento de uma unidade curricular (UC) que explorasse metodologias centradas no estudante, desta vez também com a incorporação de tecnologias educacionais. Para além de um conjunto alargado de produtores e dinamizadores do curso provenientes de ambas as IES, foi também criado um grupo de 'facilitadores' (docentes e estudantes) que acompanharam o trabalho prático dos docentes em sessões síncronas. Inscreveram-se 200 docentes (100 de cada uma das IES), organizados em 16 grupos que reuniam professores de ambas as instituições e de diversas áreas de conhecimento, sendo que cada grupo teve quatro facilitadores (um docente e um estudante de cada universidade).

A Figura 4 sintetiza a organização geral do curso: Abertura/Meet up; quatro módulos (Blended learning; Metodologias e tecnologias; Avaliação na aprendizagem; Avaliação da transformação); Apresentação de projetos. As temáticas da humanização do ensino e da constituição de comunidades de prática foram desenvolvidas transversalmente aos módulos. 


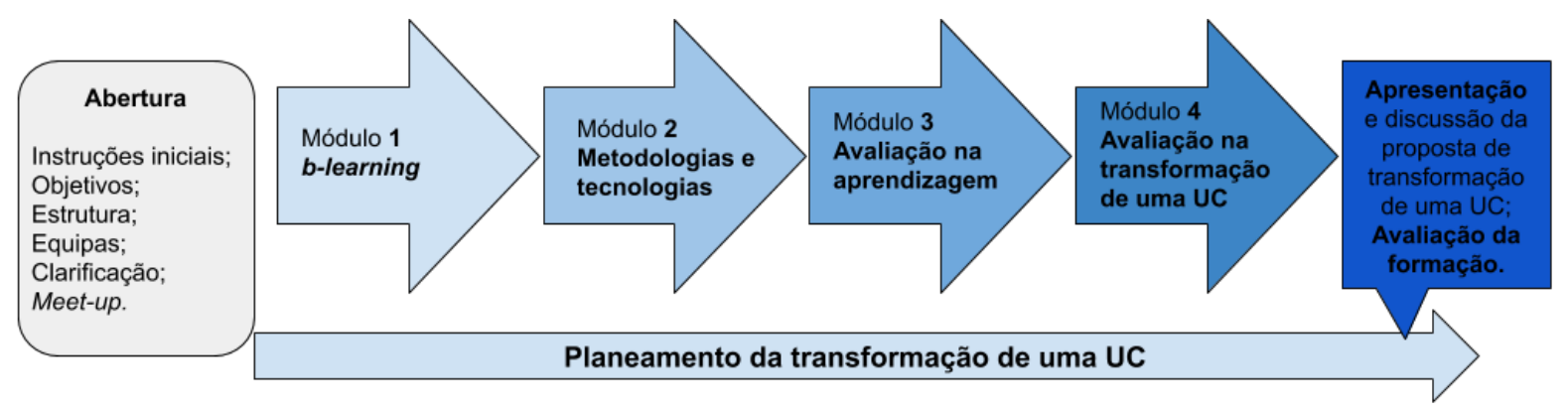

Figura 4. Organização geral do curso Docênciat.

Ocorreram seis encontros síncronos durante duas semanas (segunda, quarta e sexta, das $16 \mathrm{~h} 30$ às 19h00), sendo o primeiro dedicado à abertura oficial, Meet up (atividades para os participantes dos grupos se conhecerem e organizarem) e apresentação do módulo 1 . A partir dos encontros seguintes, a primeira parte, com maior tempo, era dedicada à apresentação e discussão do módulo em grupos (breakout rooms), reservando-se 30 minutos finais para a introdução do módulo seguinte. $\mathrm{O}$ último encontro foi dedicado à apresentação dos projetos das UC em pequenos grupos, além da avaliação geral do evento, fechando-se o mesmo com um sunset virtual.

Toda a estrutura do evento, incluindo vídeos de apresentaçôes, guiōes, materiais, avaliações, certificações e trabalhos, foram organizados em Murais do Padlet ${ }^{19}$, partindo de um mural Padlet agregador ${ }^{20}$, estimulando-se cada professor a criar o seu próprio Padlet e a postar no seu grupo, utilizando-o como um e-portefólio que integrasse o projeto de transformação de uma UC para o ano letivo de 2020-2021.

Aplicou-se um questionário de avaliação do curso, com 170 respostas, constatando-se que, na globalidade, os participantes consideraram a formação relevante para a sua formação, indicando a necessidade de mais tempo para discussões em grupo e o planeamento das UC. Destaca-se que $90 \%$ dos docentes tencionam aplicar os planos nas suas UC, sendo que somente 3,6\% consideraram que o plano desenvolvido não é aplicável, o que indica a relevância da formação na transição para o b-learning. Além disso, numa escala de 1 (mínimo) a 5 (máximo) para recomendação da formação a um

19 https://padlet.com.

20 https://padlet.com/docenciamais/transformacao. 
colega, $84 \%$ indicaram o ponto 5 e $14 \%$ indicaram ponto 4 , o que demonstra uma satisfação significativa com o curso. Apresenta-se na Figura 5 a nuvem de palavras gerada a partir da questão "Por favor, indique três aspetos que valorizou particularmente nesta formação". Destaca-se a ocorrência das palavras partilha (38), aprendizagem (21), estudantes (19), ferramentas (17) e metodologias (17), o que corrobora a perceção dos organizadores de que os momentos de partilha e diálogo foram vitais para a formação, tal como a aprendizagem de novas metodologias e ferramentas educacionais.

Concluíram o curso 166 professores, com obtenção de badges de certificação digital, tendo sido apresentados 157 projetos de planeamento de UC em modelo híbrido. Contou-se com 15 apresentadores de casos durante os módulos, 51 facilitadores e 30 organizadores (alguns atuaram em mais de um papel). Considerando a elevada procura do curso durante o período de inscriçóes, decidiu-se voltar a oferecê-lo de 14 e 25 de setembro de 2020, para mais 200 professores das duas IES.

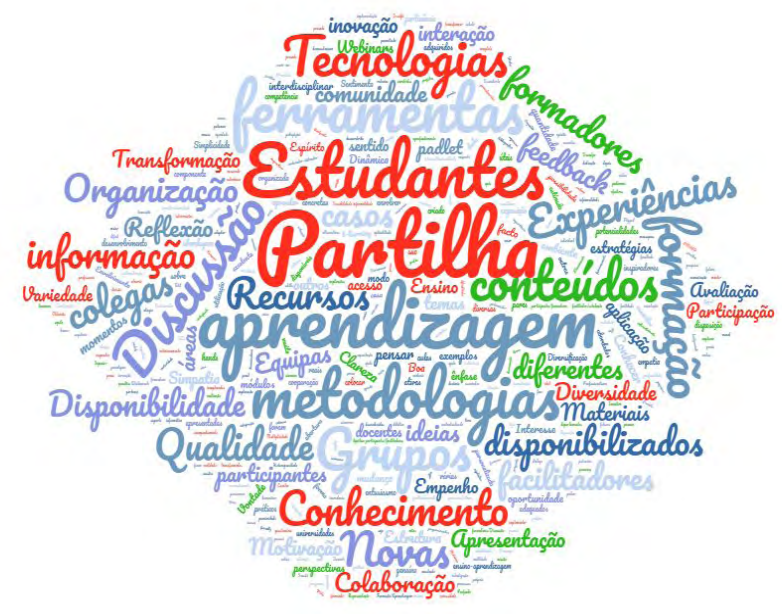

Figura 5. Nuvem de palavras gerada a partir do questionário de avaliação final: aspetos positivos da formação.

Após esta edição do Docênciat, sentiu-se a necessidade de criar um canal no YouTube ${ }^{21}$ (Figura 6), onde pudessem ser postados os vídeos e casos. Os vídeos foram organizados em playlists, correspondentes aos módulos do curso e aos webinars. Foram

21 https://www.youtube.com/c/docenciamais. 
inseridos links para os canais das Universidade de Aveiro e do Minho e das associações estudantis de ambas as instituições, reforçando-se desta forma o potencial alcance das produçốes educacionais resultantes do curso, o engajamento dos participantes e a partilha de práticas educativas.

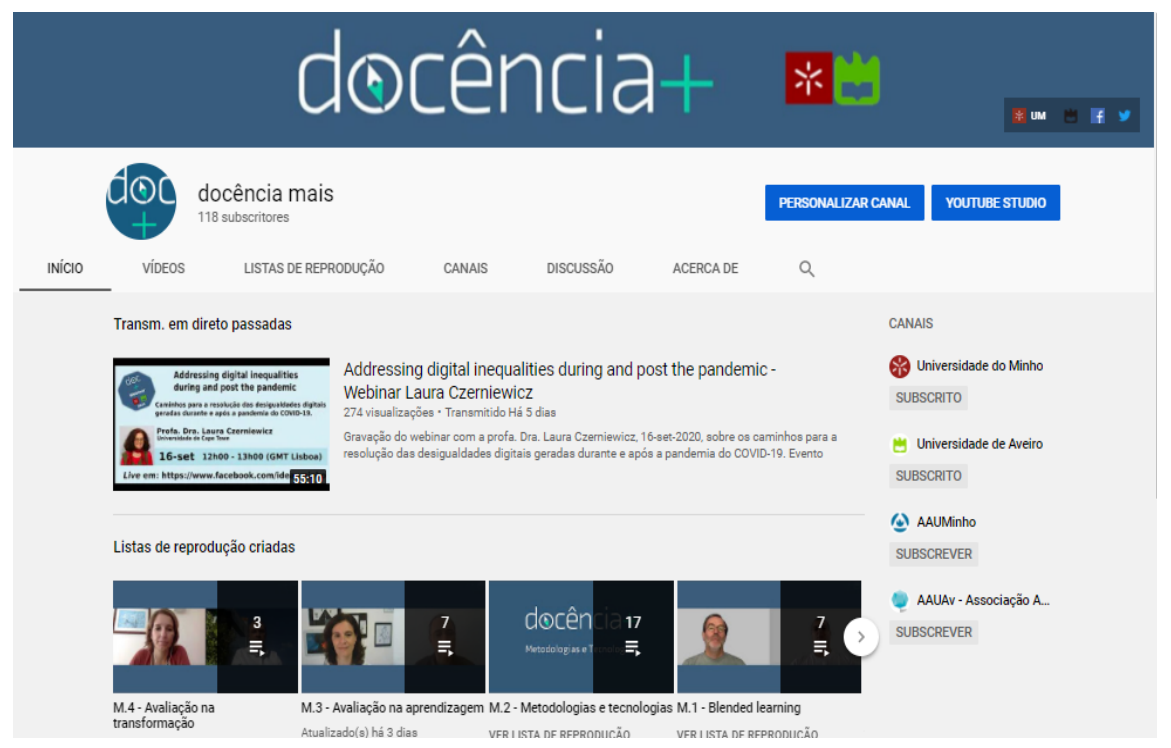

Figura 6. Captura do ecrã com a abertura do canal no YouTube.

\section{Open Badges - certificação da formação}

Uma vez que as atividades de formação foram todas desenvolvidas em ambiente virtual, a equipa sentiu a necessidade de criar uma forma de certificar a participação digitalmente, usando um sistema que fosse fácil de gerir e tivesse reconhecimento institucional e validade internacional. Após a avaliação de diversas possibilidades, optou-se pelo uso de Open badges a partir da plataforma Badgr, certificada pela IMS Global Learning Consortium, na qual foi estruturada e implementada a edição de badges. Os Open Badges foram criados pela Mozilla Foundation e são certificados digitais da participação ou realização de atividades, agregando valor ao currículo dos participantes e estimulando-os à realização das atividades. Foram criados badges para a iniciativa Partilhando IDEiAs (a partir da sessão 9), os Flipped Webinars e o curso Docência+, no qual se certificaram os inscritos que estiveram presentes nas sessóes síncronas e que realizaram as atividades assíncronas e o projeto final para uma UC em blended 
learning. Ainda no Docência +, criaram-se badges para os facilitadores e organizadores do curso, assim como para o webinar de Roni Robert. No total, foram emitidos 1.135 Badges, 716 pelas ações do Centro IDEA e 419 no âmbito do Docência +, os quais podem ser visualizados nas páginas públicas do Centro ${ }^{22}$ e do Docência ${ }^{23}$. O Quadro 6 indica os badges emitidos nas várias iniciativas.

Quadro 6. Badges das ações de formação desenvolvidas.

\begin{tabular}{|c|c|c|c|c|c|}
\hline Iniciativas & Requisitos & Evidências & Badges & Emitidos & Destinatários \\
\hline Partilhando IDEiAs ${ }^{*}$ & $\begin{array}{l}\text { Estar inscrito e } \\
\text { participar na sessão }\end{array}$ & $\begin{array}{l}\text { Participação ativa na } \\
\text { sessão }\end{array}$ & & 217 & Aberto \\
\hline Flipped webinars ${ }^{* *}$ & $\begin{array}{l}\text { Assistir ao vídeo prévio } \\
\text { e participar na sessão }\end{array}$ & $\begin{array}{l}\text { Participação ativa na } \\
\text { sessão }\end{array}$ & & 417 & Aberto \\
\hline Webinar & Participar na sessão & $\begin{array}{l}\text { Presença no Zoom } \\
\text { ou Live-redes }\end{array}$ & & 82 & Aberto \\
\hline $\begin{array}{l}\text { Webinar } \\
\text { (Roni Robert) }\end{array}$ & Participar na sessão & $\begin{array}{l}\text { Presença no Zoom } \\
\text { ou Live-redes }\end{array}$ & & 157 & Aberto \\
\hline Docência+ & $\begin{array}{l}\text { Concluir todos os } \\
\text { módulos e entregar o } \\
\text { projeto da UC }\end{array}$ & $\begin{array}{l}\text { Indicação pelos } \\
\text { facilitadores e } \\
\text { apresentação do } \\
\text { planeamento }\end{array}$ & & 166 & $\begin{array}{l}\text { Inscritos } \\
\text { transformação }\end{array}$ \\
\hline $\begin{array}{l}\text { Docência+ } \\
\text { (apresentador de } \\
\text { exemplo de prática } \\
\text { pedagógica) }\end{array}$ & $\begin{array}{l}\text { Apresentar um estudo } \\
\text { de caso durante algum } \\
\text { dos módulos }\end{array}$ & $\begin{array}{l}\text { Apresentação do } \\
\text { caso durante a sessão }\end{array}$ & & 15 & Apresentadores \\
\hline $\begin{array}{l}\text { Docência+ } \\
\text { (Facilitador) }\end{array}$ & $\begin{array}{l}\text { Atuar como facilitador } \\
\text { durante a formação }\end{array}$ & $\begin{array}{l}\text { Participação ativa na } \\
\text { formação }\end{array}$ & Facilitador & 51 & Facilitadores \\
\hline $\begin{array}{l}\text { Docência+ } \\
\text { (Organizador) }\end{array}$ & $\begin{array}{l}\text { Atuar na organização/ } \\
\text { gestão das atividades }\end{array}$ & $\begin{array}{l}\text { Participação na } \\
\text { organização }\end{array}$ & & 30 & Organizadores \\
\hline
\end{tabular}

*A partir da sessão 9, como opcional. ${ }^{* *}$ A partir da segunda oferta, como opcional.

22 Página pública Centro-IDEA: https://eu.badgr.com/public/issuers/ZqWLATSCQcGVUJ3JBZNv7g/badges. 23 Página pública Docência+: https://eu.badgr.com/public/issuers/hzBfTBLSQxCTnZA6l2Uy1Q/badges. 


\section{PERCEÇÕES DA COMUNIDADE ACADÉMICA SOBRE AS AÇÕES DESENVOLVIDAS}

A participação da equipa do Centro IDEA nas açốes desenvolvidas permitiu observar impactos positivos na comunidade académica. Para obter as perceçóes dos docentes, ainda que parciais, foi elaborado um questionário dirigido aos docentes das 11 Unidades Orgânicas da UMinho, disponibilizado online em 20/05/20 e que, portanto, não abrangia o curso Docência +. Obtivemos 73 respostas de docentes de 10 Unidades Orgânicas.

Foi solicitado aos docentes que avaliassem a utilidade das açóes na fase de transição para o ensino online, usando uma escala de 1 (Nada útil) a 5 (Muito útil). Apresenta-se no Gráfico 6 a distribuição das respostas relativas somente a quem indicou ter participado na respetiva ação. A grande maioria dos respondentes (67) participou nas sessões Partilhando IDEiAs, mas ainda assim as respostas relativas a cada ação fornecem indícios da sua utilidade. Em geral, todas as ações foram bem avaliadas, com maior percentagem de respostas na opção Muito Útil, sendo a soma das respostas nos pontos 4 e 5 da escala muito significativa, especialmente nas ações Partilhando IDEiAs, Boletim IDEAdigital e Flipped Webinars, corroborando a perceção da equipa IDEA e o nível elevado de engajamentos e alcance obtidos na divulgação das ações nas redes sociais.

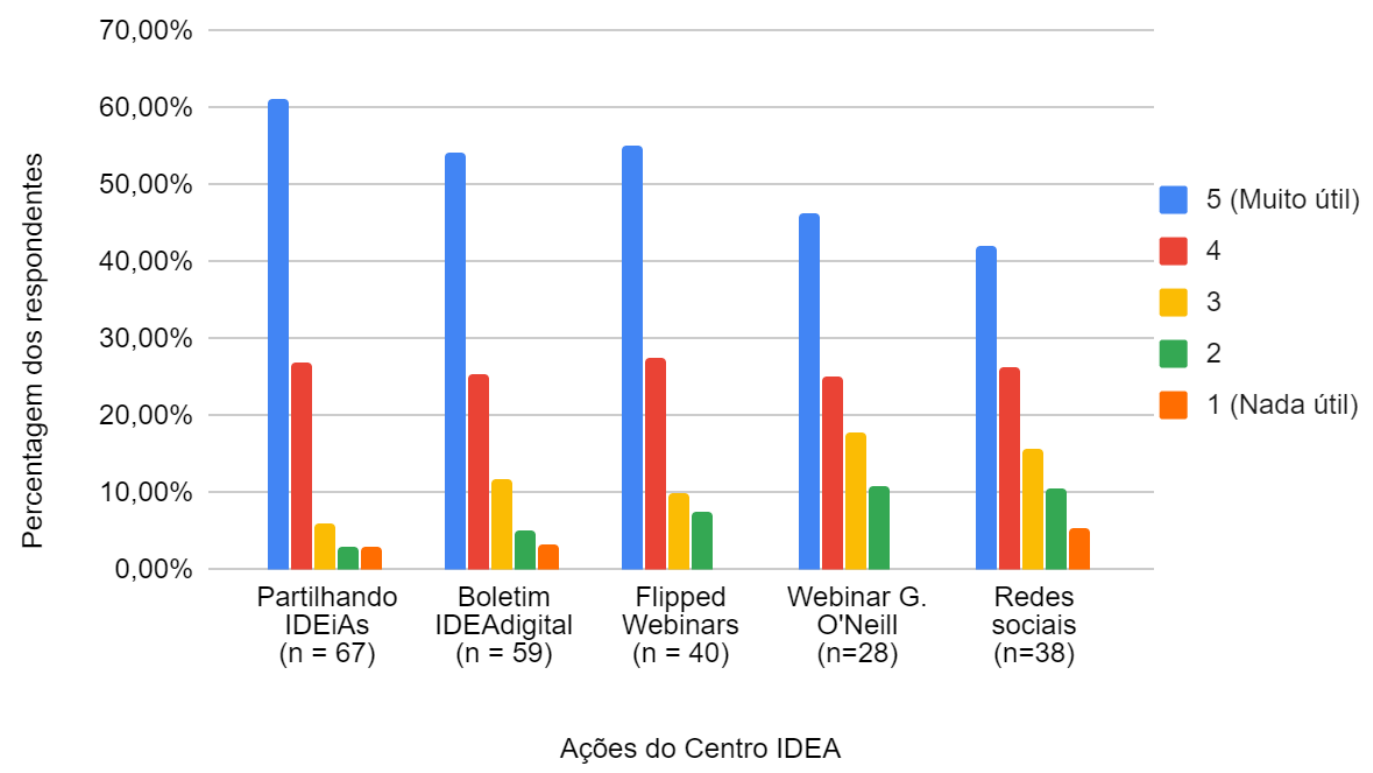

Gráfico 6. Perceçôes da utilidade das ações do Centro IDEA. 
Para compreender um pouco melhor os dados, solicitámos que os respondentes justificassem as respostas, das quais extraímos alguns excertos:

Uma delas permitiu aplicar no contexto das minhas UC essa ferramenta. Por outro lado, o 'partilhando ideias' tem sido “terapêutico" enquanto validação e empatia com o que outros colegas pensam, sentem e fazem. No meio da incerteza é bom sentirmos que alguém nos põe a mão.

Estas ações permitiram o acesso a várias ferramentas, o que, sozinha, certamente seria mais difícil.

Para além do desenvolvimento de competências e das aprendizagens face aos recursos e ferramentas digitais existentes e disponíveis, o sentimento de comunhão, partilha e solidariedade foi importante para percebermos que não estávamos sós e que as nossas dificuldades eram as dificuldades de muitos.

Foi nestes 'partilhando ideias' que surgiram muitas respostas às minhas dúvidas. Foi bom poder aprender com a experiência dos outros. Senti que estava menos isolada. Muito obrigada.

Participei destes quatro encontros [flipped webinars], todos ofereceram ideias, aplicativos e estratégias perfeitamente possíveis de ser aplicadas.

Tudo o que foi partilhado me pareceu muitíssimo interessante. $\mathrm{O}$ ambiente descontraído e aberto em que decorrem as sessões constitui também um contributo importante para encarar com serenidade os desafios e saber que não estamos sozinhos nesta aventura!

Webinar com Geraldine O’Neill ajudou clarificar muitas dúvidas.

As publicações nas redes sociais servem muitas vezes de inspiração e ajudam a conhecer a realidade de outros contextos, sobretudo os mais avançados, com os quais podemos aprender e melhorar e/ou simplesmente repensar as nossas práticas pedagógicas.

$\mathrm{Na}$ globalidade, estes excertos sublinham a natureza reflexiva e dialógica das iniciativas desenvolvidas, assim como a sua importância para a renovação das práticas, e 
expressam o potencial humanizador de açóes coletivas em momentos críticos, como era o que vivíamos. Estas ideias são reforçadas na nuvem de palavras da Figura 7, construída a partir de todas as respostas a esta questão $(n=52)$, a qual indica a predominância de palavras como partilhar, participar, aprender, ideias, experiências, estratégias, dificuldades, sentimento e apoio.

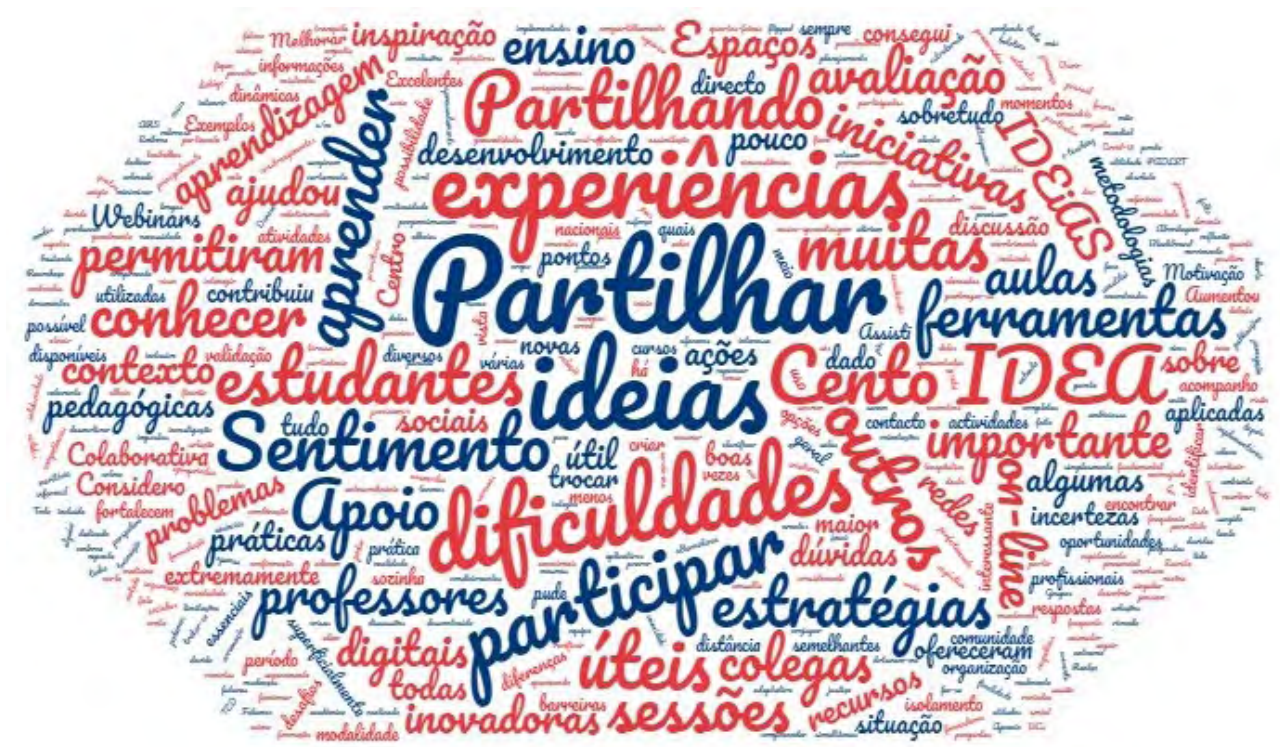

Figura 7. Nuvem de palavras gerada a partir das perceçôes da utilidade das açóes do Centro IDEA.

Além deste questionário, após a sessão 8 da iniciativa Partilhando IDEiAs (20 de maio de 2020), na qual estavam presentes os presidentes dos Conselhos Pedagógicos, solicitámos que estes continuassem na reunião para podermos questioná-los sobre a perceção que tinham do papel/impacto das açóes do Centro IDEA no momento de transição para o ensino online e sobre cursos ou outras açôes que poderiam ser realizadas. Uma vez que estávamos pós-sessão do Partilhando IDEiAs, o diálogo acabou por ficar centrado nesta iniciativa, sendo ressaltada a sua importância como um suporte psicológico à comunidade, uma forma de manter a humanização nas relaçôes durante a pandemia, possibilitando a partilha de dificuldades e ideias, assim como uma visão mais transversal dos problemas sentidos, conforme os seguintes testemunhos: 
[...] ter relações individualizadas, pessoais, saber um pouco dos outros [...] manter a relação humanizada.

[...] ter oportunidade de refletir, falar das incertezas, medos, ansiedades [...]

[...] esta sessão deixou-me muito tranquilo, pois vejo que muitos dos problemas são transversais [...] percebi que há um maravilhoso mundo novo que descobrimos [...]

Os presidentes dos Conselhos Pedagógicos destacaram a importância das ações do Centro naquele momento de transição, destacando a necessidade de consolidar práticas e replanear o ensino com recurso a modalidades de blended learning para o ano letivo seguinte, assim como dar continuidade e expandir as ações de formação oferecidas pela UMinho e pelo Centro IDEA.

\section{REFLEXÕES FINAIS E PERSPETIVAS FUTURAS}

A realidade da pandemia trouxe mudanças na educação com um alcance ainda por conhecer na sua globalidade, obrigando a um movimento rápido e urgente de transformação de modos de pensar e fazer no ensino superior, e ao desenvolvimento de novas competências dos docentes e estudantes. Foi neste cenário que a equipa do Centro IDEA-UMinho desenvolveu as ações aqui apresentadas, com múltiplas colaborações, no sentido de propiciar espaços, meios e ferramentas que facilitassem a transição para o ensino online, designado por muitos por 'ensino remoto emergencial', num tempo que foi exíguo e em grande medida desconcertante, exigindo um enorme esforço e resiliência de todos os envolvidos.

Entretanto, os esforços não podem parar. Manter um ensino de qualidade na Universidade depende de um planeamento estratégico e da criação de oportunidades de formação e desenvolvimento profissional e é nessa perspetiva que o Centro IDEA pretende caminhar, reaproveitando, recriando e transformando as açóes realizadas, para que os processos de ensino e aprendizagem avancem no sentido da integração de tecnologias digitais em abordagens centradas nos estudantes, não apenas a curto prazo, mas também num horizonte temporal mais alargado, quando o ensino a distância 
deixar de ser uma necessidade incontornável e passar a ser uma escolha dos docentes que o quiserem explorar, nas suas diversas modalidades e em conjugação com o ensino presencial. Acreditamos que as ações desenvolvidas abriram caminho para repensar o ensino e a aprendizagem, e o papel que as tecnologias poderão desempenhar numa educação de qualidade.

Uma das maiores aprendizagens desta experiência foi compreender o potencial de um trabalho coletivo e de sentido comunitário, ao serviço de cada um e de todos, o que implica a criação de espaços de diálogo e colaboração, a construção de comunidades de prática e o reforço de parcerias intra/interinstitucionais. As ações do Centro IDEA deram e continuarão a dar um impulso importante a estes eixos de desenvolvimento estratégico, mas será necessário consolidar políticas, apoios e condições de sustentabilidade da mudança, assim como promover o envolvimento dos docentes, dos estudantes e das estruturas de gestão na sua operacionalização, monitorização e avaliação.

\section{REFERÊNCIAS}

Castman, A. S., \& Rodrigues, R. A. (2020). Educação a Distância na crise COVID - 19: Um relato de experiência. Research, Society and Development, 9(6), 1-26. https://rsdjournal.org/index.php/rsd/article/ view/3699.

Chalmers, D., \& Gardiner, D. (2015). The measurement and impact of university teacher development programs. Educar, 51(1), 53-80.

Manca, S. (2020). Snapping, pinning, liking or texting: Investigating social media in higher education beyond Facebook. The internet and Higher Education, 44, 1-13. Disponível em: https://doi.org/10.1016/j. iheduc.2019.100707. Acesso em 15 jun. 2020.

Santos Jr.,V. R., \& Monteiro, J. C. S. (2020). Educação e COVID-19: As tecnologias digitais mediando a aprendizagem em tempos de pandemia. Revista Encantar: Educação, Cultura e Sociedade, 2, 1-15. http:// www.revistas.uneb.br/index.php/encantar/article/view/8583

Steinert, Y., Mann, K., Anderson, B., Barnett, B. M., Centeno, A., Naismith, L., Prideaux, D., Spencer, J., Tullo, E., Viggiano, T., Ward, H., \& Dolmans, D. (2016). A systematic review of faculty development initiatives designed to enhance teaching effectiveness: A 10-year update, BEME Guide No. 40, Medical Teacher, http:// dx.doi.org/10.1080/0142159X.2016.1181851.

Unesco (2020). Education: From disruption to recovery. Online dynamic data. https://en.unesco.org/ $\underline{\text { COVID19/educationresponse. }}$ 
Vieira, F., Vieira, C. P., Moreira, J. A., Silva, J. L. C., \& Gonçalves, S. (2019). Mudança pedagógica e apoio institucional ao ensino: Um estudo no contexto português. In S. Gonçalves \& C. Fidalgo (coords.), Pedagogia no ensino superior: Coletânea de estudos, CINEP, Instituto Politécnico de Coimbra, pp. 59-79. 